\title{
Heptageniidae from Corsica and Sardinia. Rhithrogena nuragica n. sp., $R$. eatoni Esben-Petersen 1912, and $R$. insularis Esben-Petersen 1913 (Ephemeroptera)
}

\author{
C. Belfiore 1
}

Kcywords : Ephemeroptera, Heptageniidae, New species, Corsica, Sardinia.

Imagines, nymphs and eggs of Rhithrogena nuragica $\mathrm{n}$. sp. are described from Gennargentu. Sardinia. Nymphs and eggs of $R$. instlaris Esb.Pet. and $R$. eatoni Esb.Pet. from Corsica are described for the first time. $R$. nuragica and $R$. insularis belong to the same species group, namely the insularis group, characterized mainly by the very peculiar tubercules on the egg chorion. Nymphs of this group have crenulated gills, femora with a median dark spot and plica on the first gill subtriangular, with a digitiform projection on the free corner. $R$. eatoni belongs to the alpestris group.

Heptageniidae de Corse et de Sardaigne. Rhithrogena nuragica n. sp., $R$. eatoni Esben-Petersen 1912, et $R$. insularis EsbenPetersen 1913 (Ephemeroptera).

Mots clés : Ephemeroptera, Heptageniidae, espèces nouvelles, Corse, Sardaigne.

Les imagos, les nymphes et les œufs de Rhithrogena nuragica n. sp. sont décrits de Gennargentu, Sardaigne. Les nymphes et les œufs de $\boldsymbol{R}$ instilaris Esb.Pet. et $\boldsymbol{R}$. eatoni Esb.Pet. de Corse sont decrits pour la premiere fois. $R$. nuragica et $\boldsymbol{R}$. insularis appartiennent au même groupe d'espèces, le groupe insularis, caractérisé essentiellement par les tubercules très particuliers du chorion de l'œul. Les nymphes de ce groupe ont les branchies crénelées, les fémurs avec une tache médiane foncée et le repli subtriangulaire de la première branchie avec un prolongement digitiforme sur le coin antéro-externe. R. eatoni appartient au groupe alpestris.

\section{Introduction}

The imagines of Rhithrogena insularis and Rhithrogena eatoni were shortly described by EsbenPetersen (1912, 1913) from Corsica. Sowa (1971) redescribed males of both species from type material; Sowa (1984) referred the former species to the hybrida group, the lat ter to the semicolorata group on the basis of genital apparatus of the male imagines.

I have examined material collected in 1986 from several localities of Corsica and I have found both Esben-Petersen's species. Here I describe the

1. Dipartimento di Zoologia dell'Universita di Napoli, via Mezzo cannone 8, 80134 Napoli, Italy.

Research carried out with a C.N.R. grant, 'Biologia naturalistica' group. previously unknown nymphs of the two species. The species attribution of nymphs was made examining the eggs of fernale mature nymphs, which have a very distinetive chorionic pattern. I describe also a new species closely related to $R$. insularis, $R$. nuragica n. sp., from Sardinia.

\section{List of localities}

Sardinia, Gennargentu : S1- Strada provinciale N. 7 (Nuoro), Km 21.5, Rio Aratu, 31.5.1985 ; S2- Strada provinciale N. 7 (Nuoro), Rio Badule Spano, 31.5.1985 ; S3-Desulo (Nuoro), right tributary of Flumendosa River, 2-4.6.1985.

Corsica: C1-Corte, R. Restonica, P. de Tragone, $943 \mathrm{~m}, 6.6 .1986 ; C 2$ - Albertacce (Calacuccia), R. Golo, $840 \mathrm{~m}, 7.6 .1986 ; \mathrm{C} 3$ - Forete de Valdo-Niello, right trib. R. Golo, $1000 \mathrm{~m}, 7.6 .1986$; C4.Asco, R. 
Stranciacone, $750 \mathrm{~m}, 8.6 .1986$; C5- Haut Asco, R. Stranciacone, $1100 \mathrm{~m}, 8.6 .1986$; C6-Asco, R. Stranciacone, $1000 \mathrm{~m}, 8.6 .1986$; C7-Corte, R. Restonica, $700 \mathrm{~m}$, (a) 8.6.1986, (b) 12.9 .1986 ; C8-Vizzavona, right trib. R. Vecchio, Tat tone, 9.6 .1986 ; C9- Bocognano, R. Gravona, N193, 9.6.1986; C10-Bastelica, R.Volta, 771 m. 10.6.1986; C11-Val d'Fse, R. Ese, 10.6.1986; C12 - Palneca, R. Taravo, $800 \mathrm{~m}$, 11.6.1986; C13-Col de Verde, R. Taravo, 11.6.1986; C14-Cristinacce (Evisa), R. Tavulella, $765 \mathrm{~m}$. 7.6.1986; C15- Col de Marcuccio, left trib. R. Prunelli, Zipitoli, 10.6.1986 ; C16-Sampolo (Ghisoni). Fium'Orbo, 11.6.1986.

C. Belfiore leg.; all material is in the Author's collection.

\section{Descriptions of species}

\section{Rhithrogena nuragica $\mathrm{n}$. sp.}

Etymology : nuragica from the ancient Nuragic civilization which arose in Sardinia on the 2 nd millennium b.C.

Material. Holotype: S1- 1 or ; paratypes: S1. 4 $\sigma \sigma, 4$ nymphs ; $\$ 2.1 \sigma, 1$ Q, 4 nymphs ; $33-3 \sigma \sigma$, $1 \%, 4$ nymphs. Other material: S1: $3 \% \%, 10$ nymphs; $S 2: 1 \%, 14$ nymphs; $S 3: 67$ nymphs.

Male imago. Body length $12 \mathrm{~mm}$, fore wing $12 \mathrm{~mm}$. Medial part of eyes pinkish grey, lateral part grey with an indistinct light stripe. Thorax middle brown. Wing very slightly tinged with brownish. Transverse veins well marked, brown. Distal half of costal area opaque, yellowish brown. Costa, Subcosta and other longitudinal veins brown. Fore legs brown, femur with a narrow medial dark stripe. Mid and hind legs lighter, yellowish brown, femora with a subtriangular dark spot. Tergites II-VII yellowish to reddish brown, becoming darker towards hind margin. Abdominal pattern similar to $R$. insularis (Sowa 1971 : Fig. 24). Sternites lighter, without markings. Hind margin of IX stemite with a deep medial emargination (Fig. 13). Penis lobes, from ventral view, relatively short and stout, darker on owter half, with an evident inner spine (Figs. 1-2). From hind view, the genital opening appears rounded (Fig. 8). Titi]. lators wide, with small denticles (Fig. 7).

Female imago. Body length 10-11 mm. Body colouration and marking similar to male imago, with a more intense reddish tinge. Sternites with hardly visible, pale nervous ganglia.
Egg (from female imago and female mature nymphs). Chorion very peculiar, with small tapering tubercles, evenly distributed on the egg surface (Figs. 17-18). Adhesive coils lacking.

Nymph. 9-11 mm. 8-9 comb-shaped bristles on fore margin of maxilla, with 9.11 teeth. Glossae subtriangular, wide, with outer margin sinuous (Fig. 22). Lateral sclerites of the first abdominal sternite with fore margin perpendicular to the longitudinal body axis (Fig. 19). Coxae with a dark stripe near the outer margin of distal corner. Femora with a rounded dark spot, sometimes hardly visible, at the centre of the median pale area (Fig. 28). Bristles on femora short and rounded, with diverging sides (Fig. 25ab). Sometimes there is a rounded brown area near the basis of these bristles. Bristles on dorsal side of hind tibia wide, with diverging sides (Fig. 25 c). Generally two denticles on tarsal claws. All lamellae of gills crenulated (Fig. 31). Plica on the first gill subtriangular, the free corner has a more or less developed finger-like projection.

\section{Rhithrogena insularis Esben-Petersen, 1913}

Material. C1- 6 nymphs ; C2- 15 nymphs; C3- 49 nymphs : C4- 14 nymphs, 1 o, 1 \%; C5. 7 \% \% : C6 28 nymphs; $C 7$ (a) 27 nymphs, 16 \%; C8. 6 nymphs ; C9- 59 nymphs ; C10- 3 nymphs ; C11. 8 nymphs, $2 \sigma \sigma, 1 \%$ : C12- 17 nymphs; C13. 5 nymphs.

Male imago. Body length $10 \mathrm{~mm}$, forewing $11 \mathrm{~mm}$. Colours and markings like $\boldsymbol{R}$. nuragica, fore legs slightly lighter. None of the examined specimens had the dark nervous ganglia described by Esben Petersen (1913) and Sowa (1971). Penis lobes from ventral view slender (Figs. 3-4), with a distal rounded projection; outer tooth not visible, inner tooth well developed. From hind view the genital opening is elongated (Fig. 10). Titillators slim, subtriangular, with few denticles (Fig. 9).

Fermale imago. Thorax light brown, darker towards hind margin. Abdominal marking more indistinct than male. Femora with narrow subtriangular reddish brown spot on the central area.

Egg (from female imago and female mature nymph). Chorion covered with large cylindrical tubercules, which have several small blunt tips on the apex (Figs. 15-16). Adhesive coils lacking. 

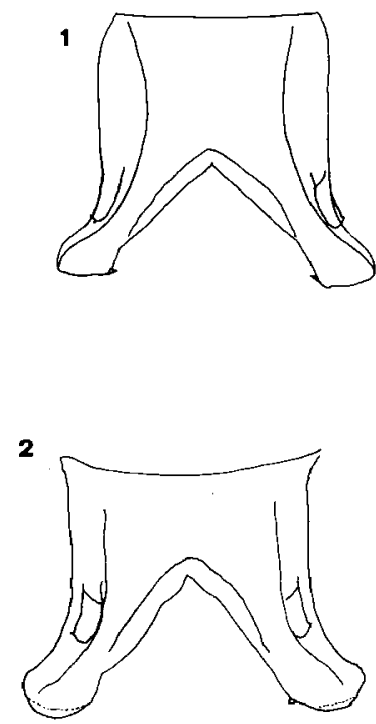

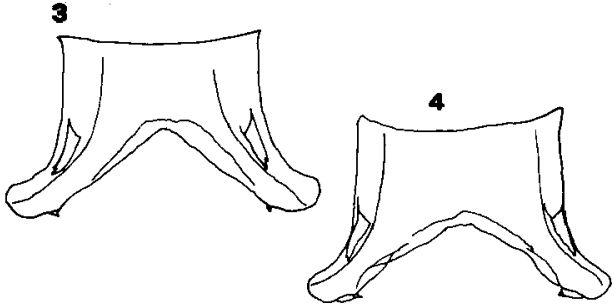

6
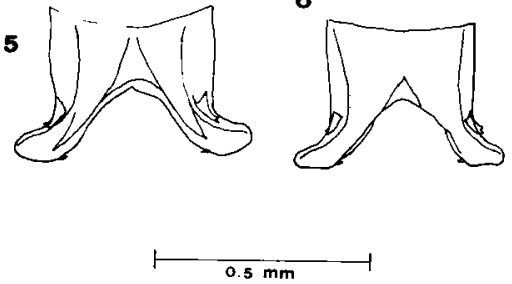

Fig. 1 to 6. Penis lobes from ventral view. Fig. 1-2:R. nuragica n. sp., two specimens. Fig. $3-4: R$. insularis Esben Petersen, two specimens. Fig. 5-6:R eatoni Esben Petersen, two specimens.

Nymph. Body length 8-11 mm. Glossae generally subovoidal, narrow, with rounded apex (Fig. 23). Coxae not pigmented. Femora with a large, irregular reddish spot on the centre of dorsal side. Bristles on femora generally more longer and narrower than $R$. nuragica (Fig. 26a-b). Dorsal bristles on hind tibia very long (Fig. 26c). Two denticles on tarsal claws. Lamellae of gills crenulated (Fig. 32). Plica on the first gill like $R$. nuragica.

\section{Rhithrogena eatoni Esben Petersen, 1912}

Material. C5- $102 \% \sigma, 1$ \% ; C7-(b) $3 \sigma \%$; C1417 nymphs; C15- 3 nymphs; C16- 33 nymphs.

Male imago. Body length $9 \mathrm{~mm}$, forewing $8.5 \mathrm{~mm}$. Eyes yellowish orange in living specimens, pinkish in preserved material. Lateral part of eyes with an evident light stripe between two dark grey bands. Thorax dark brown, pleurae with whitish markings. All legs pale yellowish with dark joinings. Fore femur has a wide dark reddish spot, mid and hind femora with a narrower subtriangular spot. Wings hyaline, proximal half of Subcosta and Radius light brown, other veins violet. First transverse vein on costal area blackish violet. Other transverse veins on proximal half of costal area hardly visible. Distal half of costal area opaque, whitish. Abdomen with distinctive markings: sides of tergites with wide oblique dark reddish brown bands, medially not connected. Sternites pale. Hind margin of IX sternite not deeply excised, with a rounded or angular emargination (Fig. 14). Penis resembles in general shape that of $R$. alpestris (Puthz 1975 : Fig. 8). Apex of penis lobes, from ventral view (Figs. 5-6), more or less bent outwards, inner tooth well 

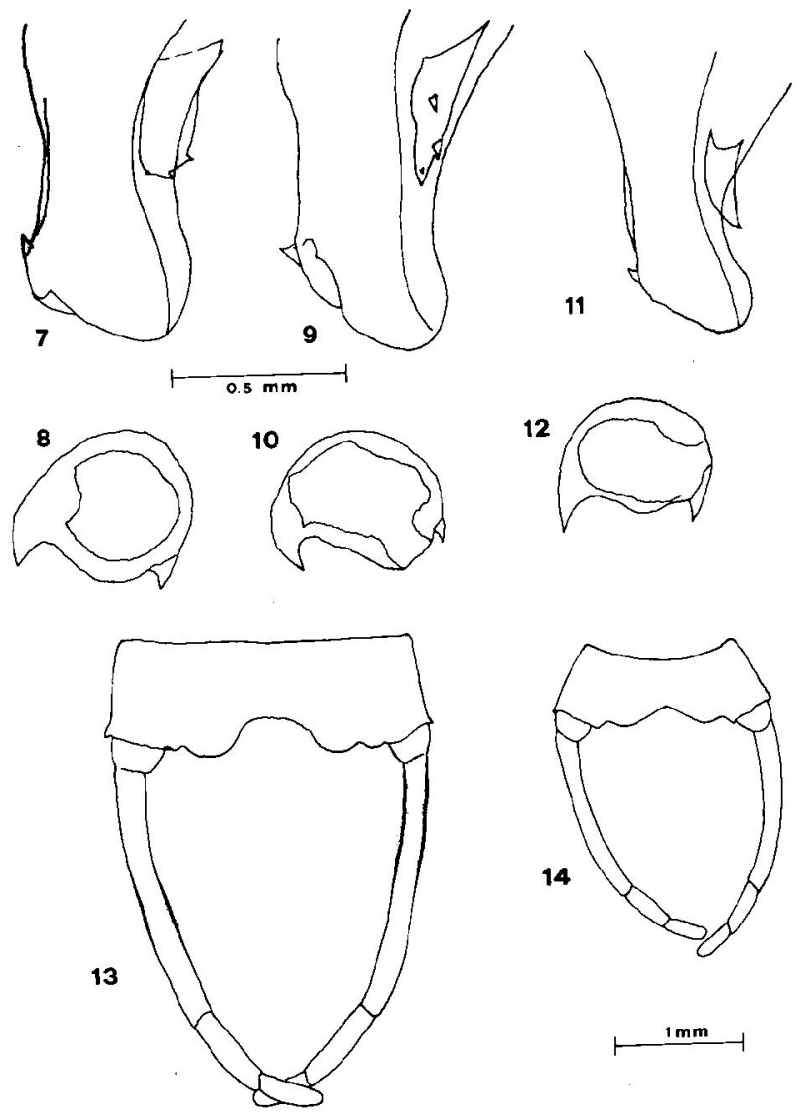

Fig. 7 to 14. Penis lohes from ventral $(7,9,11)$ and hind view $(8,10,12)$; IX sternite and gonopodes $(13,14)$ Fig. $7,8,13$ : $R$. nuragica n. sp. Fig. 9, 10: $R$. insularis Esben-Petersen. Fig. 11,12,14: $R$. eatoni Esben Petersen. 

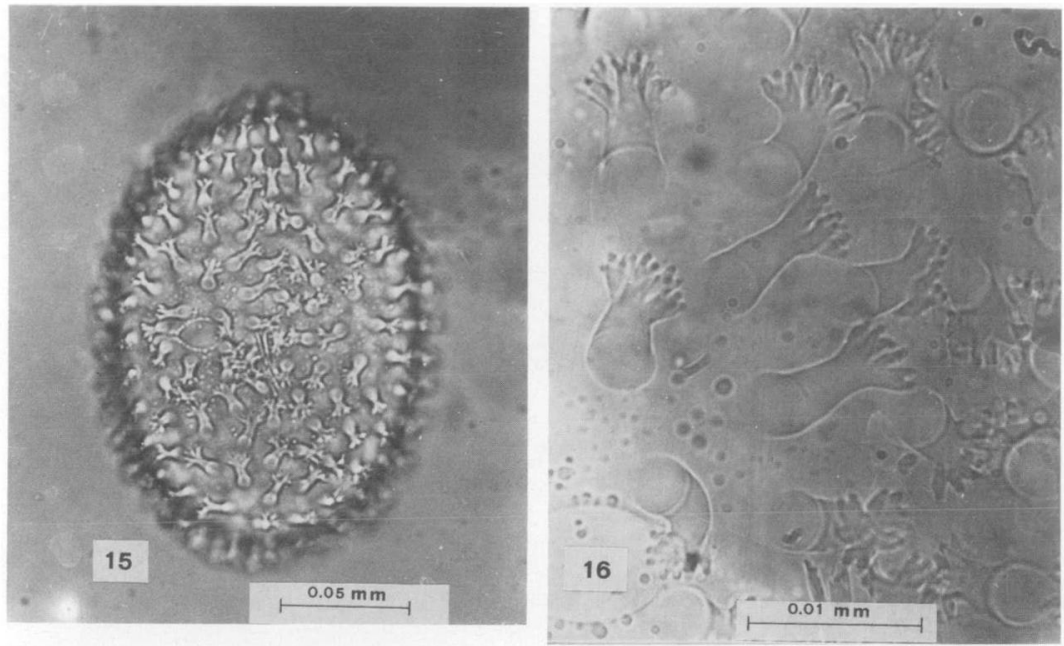

Fig. 16 to 18 . Eggs $(15,17)$ and chorionic tubercules $(16,18)$. Fig. 15,16: $R$. insularis Esben Petersen
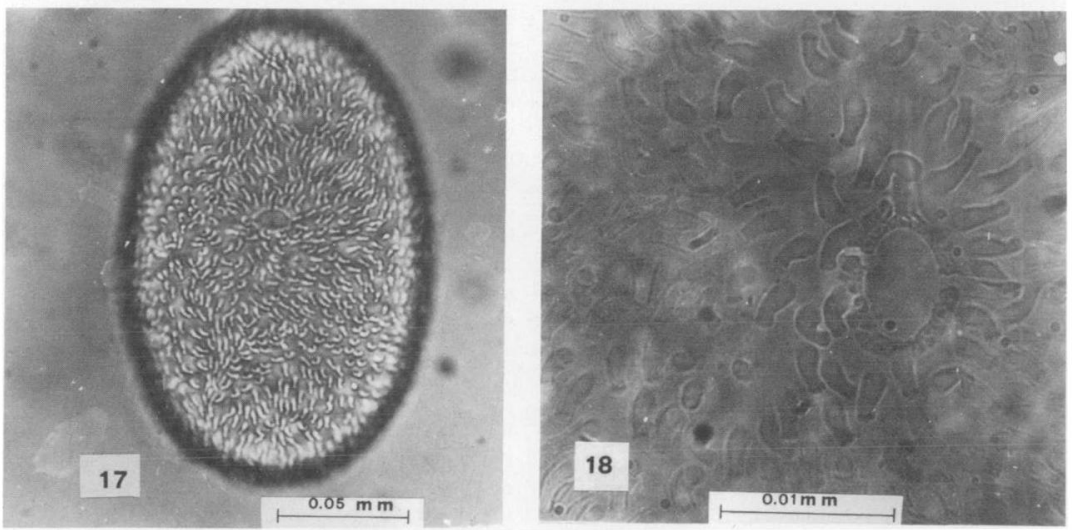

Fig. $17,18: R$. nuragica n. sp 

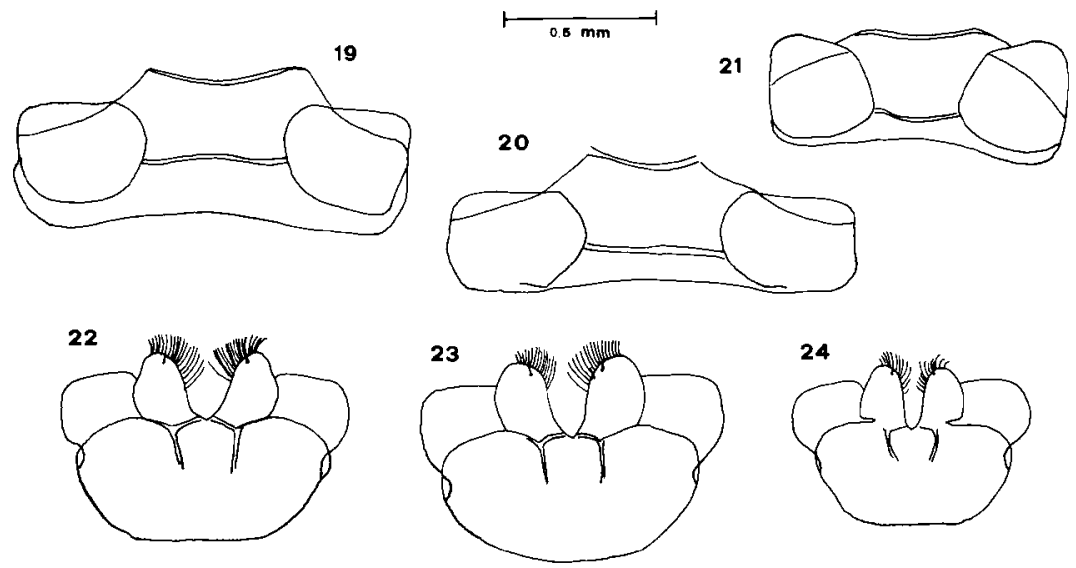

Fig. 19 to 24. First sternite of nymph (19.21), glossae and paraglossae (22.24) of nymph. Fig. 19, $22: R$. nuragica n. sp. Fig. 20,23: R. insularis Esben Petersen. Fig. 21, $24: R$. eatoni Esben Petersen.

developed. From hind view the genital opening is elongated (Fig. 12). Titillators pointed or subtriangular with few denticles (Fig. 11).

Female imago. Colours and markings like the male. Proximal transverse veins on costal area light brown, more marked than male.

Egg (from female imago and mature female nymph). Chorion densely covered with large granules. Small adhesive coils uniformly distributed. Some larger coils are grouped on only one pole.

Nymph. 6-9 mm. 9-11 comb- shaped bristles on fore margin of maxilla, with 10-13 teeth. Glossae subtriangular (Fig. 24). Lateral sclerite of the first abdominal sternite with a rounded outgrowth on outer corner (Fig. 21). Coxae distally striped with brownish. Femora with a reddish irregular spot on the central pale area, sometimes hardly visible (Fig. 30). Bristles on femora with darkened basis, very short and rounded (Fig. 27a-b). Dorsal bristles on hind tibia with diverging sides (Fig. 27c). Generally two denticles on tarsal claws, the proximal one smaller, sometimes absent. Lamellae of gills crenulated (Fig. 33). First gill without a well defined plica.

\section{Discussion}

R. eatoni, previously referred to the semicolorata group (Sowa, 1984), belongs to the alpestris group. Main nymphal characters for the species-group attribution are : shape of the sclerite of first sternite, with fore margin forward directed; lamellae of gills crenulated, first lamella without dorsal plica. Nymphs of $R$. eatoni, unlike other species of the group, have femora with a reddish spot on dorsal side; furthermore the femora lack the long bristles on hind margin. Also the male imago is similar to the other species of alpestris group, mainly for the weak wing venation and shape of penis.

$R$. nuragica and $R$. insularis are undoubtedly closely related. Their species-group attribution is problematic because both species share contrasting characters. Penis lobes are hybrida -group like, plica on first gill and spots on femora of nymphs are semicolorata-group like. Moreover the eggs of $R$. insularis have very peculiar chorionic tubercles with finger-like tips at the apex. The tubercles on 

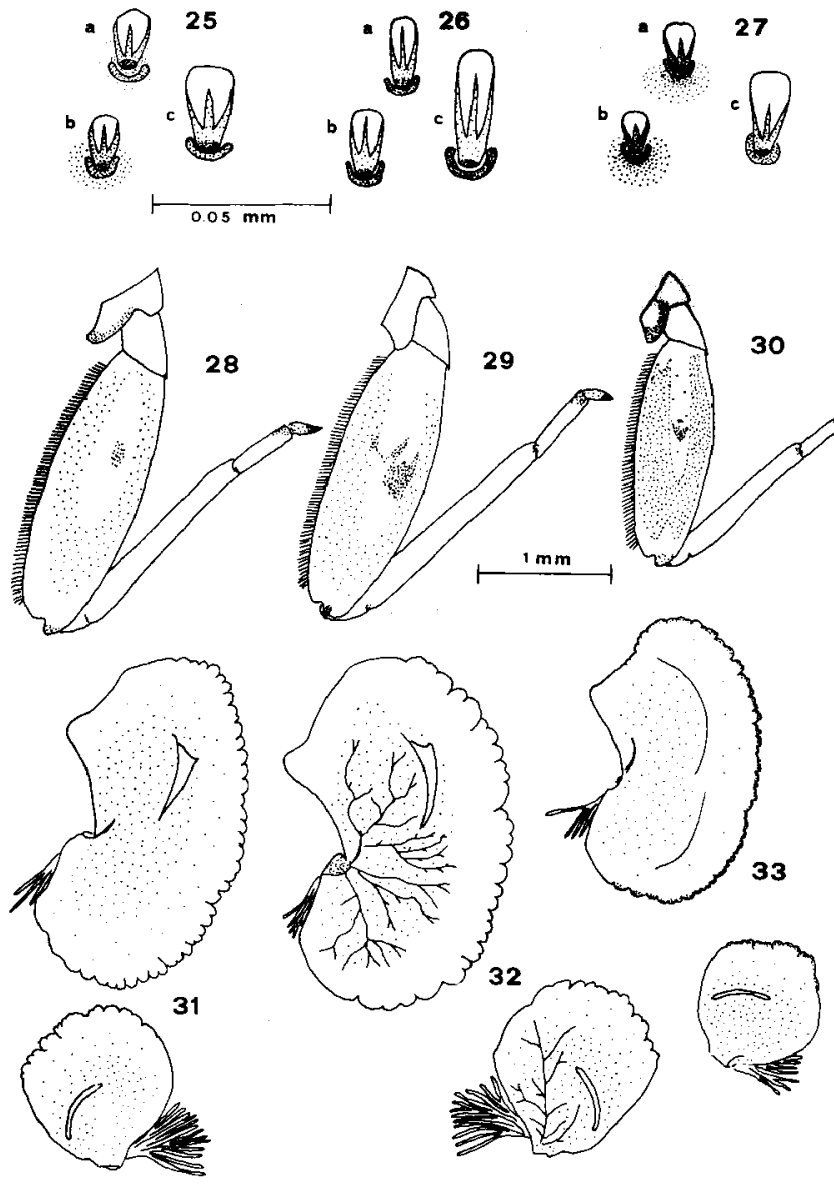

Fig. 25 to 33 Bris $i, \therefore$ on mid-, hind femur and tibia of nymph (25-27,a,b,c), hind leg (28-30), I and II gills of nymph. Fig. 25,28,31: $R$. intragica n. sp. Fig. 26,29,32: $R$. insularis Esben Petersen. Fig. 27,30,33: $R$. eatoni Esben Petersen. 
$R$. nuragica eggs are essentially of the same kind, although much smaller.

I propose to include both species in a further species group, namely the insularis group, characterized by the presence of tubercules on egg chorion and by the following nymphal characters : a dark spot on dorsal side of femora ; sclerites on first sternite with straight fore margin, perpendicular to the longitudinal body axis ; plica of first gill subtriangular, with pointed free corner; lamellae of gills crenulated.

\section{Aknowledgements}

I wish to thank Prof. R. Prota, from Sassari University, for the logistic help during the collection trip in Sardinia.

\section{Literature}

Esben-Petersen (P.) 1912. Addition to the knowledge of the Neuropterous insect fauna of Corsica. I. Ent. Medd. $4: 349-352$.

Esben-Petersen (P.) 1913. Addition to the knowledge of the Neuropterous insect fauna of Corsica. II. Ent. Medd, 10: 10-28.

Puthz (V.) 1975. Uber einige europäische Heptageniiden (Insecta, Ephemeroptera). Sur les éphéméroptères du Muséum d'Histoire Naturelle de Genève 4. Revue sutisse Zool, 82 (2) : 321-333.

Sowa (R.) 1971. Note sur quelques Rhithrogena Eaton de la collection Esben-Petersen et la redescription de Rhithrogena germanica Eaton (Ephemeroptera, Heptagenijdae). Bull. Acad. pol. Sci, 19: 485-492.

Sowa (R.) 1984. Contribution à la connaissance des espèces europeennes de Rhithrogena Eaton (Ephemeroptera, Heptageniidae) avec le rapport particulier aux especes des Alpes et des Carpates. Proc. JV int. Conf. Ephemeroptera, CSAV: 37.52. 